Edward Gillian, Bogna Ferensztajn, Bożena Franków-Czerwonko, Urszula Paradowska

Higher Vocational State School in Gorzow Wielkopolski, Gorzow Wielkopolski, Poland

\title{
Emergent literacy and numeracy- preparation for reading, writing and mathematics
}

\section{Introduction}

Little research has been carried out in the area of the relationship between the early language concepts and possible literacy difficulties among students in later school years in Poland. However, this correlation has been researched and documented in English speaking countries and developing early literacy skills seems to be one of the most important developmental stages for pre-school children.

The Polish children, especially those coming from the Lubuskie region in Poland, seem to be lacking in their literacy and mathematics skills, as proved by the data published by the Central Statistics Office and the Poznań Regional Examination Board, which concerns the average student scores in external exams for primary, middle, and secondary education. The results the Polish students in the Lubuskie region achieve are below the country's average, especially in the rural areas.

It is possible that the lack of these skills might be due to the need for the explicit teaching of early language concepts, since it was proved by the research undertaken in some Australian schools by the author, Gillian, that introducing children to emergent literacy and numeracy concepts is a beneficial preparation for their reading, writing, and mathematics skills.

The article presents the Australian research and a Polish pilot study, as well as the presently running research conducted in the Bogdaniec commune in the 
Lubuskie region, whose objective is to develop professional skills of the preschool teachers so they can explicitly teach their students these early language concepts.

The authors' intention is that this research and explicit teaching of early language concepts will improve significantly the literacy and numeracy skills among the Polish students in the Bogdaniec commune.

\section{Theoretical background}

The importance of emergent literacy, or the concepts, skills, and knowledge that are acquired before the achievement of beginning reading, spelling, and writing in English, has been well documented (Bishop \& Adams 1990, Catts 1993, Catts, Fey, Tomblin \& Zhang 2002). In particular, a component of emergent literacy, phonological awareness (PA), has been extensively researched as a foundation skill for English speaking students developing their early literacy skills (Gillon 2005, Hogan, Catts, \& Little 2005, Torgesen, Wagner \& Raschotte 1994).

Many basic oral language concepts are important literacy concepts (Justice, Kaderavek, Fan, Sofka \& Hunt 2009, Justice, Invernizzi \& Meier 2002) and also numeracy concepts (Fleer, Ridgway, Clarke, Kennedy, Robbins, May, \& Surman 2006; Pasnak, MacCubbin, \& Ferral-Like 2007). These concepts include: beginning/ end, top/bottom, big/little, same/different, and left/right (see Gillian, Ferensztajn, Franków-Czerwonko \& Paradowska, in press, for a more detailed review of these concepts).

There is a gap in the research literature about the development of emergent literacy and numeracy in Polish children. The Polish developmental norms for early language concepts crucial for literacy such as beginning/end, top/bottom, left/right, and same/different are approximately known and are reported to be similar to English developmental norms (Gruszczyk-Kolczyńska \& Zielińska 1997, Janiszewska 2008, Matczak 2003), the relationship between difficulties with emergent literacy and later literacy difficulties in Polish has not been directly established.

\section{Project description and background}

The goals of the project are provide more information on the development of basic language concepts in Polish for young students and investigate if emergent literacy difficulties exist for young Polish students, and whether there is a relationship between these difficulties and literacy difficulties in later school years. The information on basic language concepts in Polish is being researched by comparing and contrasting the known developmental norms for Polish with those of English. More specifically, the data for Polish emergent literacy norms collected by current 
authors is being compared to research undertaken by one of the authors (Gillian \& Williamson 2009) through translating the English oral language screener developed by one of the authors (Gillian) into Polish (see Figure 1 for some details about the English language screener).

\subsection{Australian research}

The research undertaken in Australia occurred at a school where the five year old students had many difficulties with oral language. The majority of the students of this school (92\%) were reported to have a first language other than English and were reported to come from lower socio-economic status backgrounds (see Gillian, Ferensztajn, Franków-Czerwonko \& Paradowska, in press, for more details). The students entering the first year of school were reported to have not mastered the emergent literacy concepts required at the start of the school year (see Gillian, Ferensztajn, Franków-Czerwonko, \& Paradowska, in press, for more details). The students were given explicit teaching in these concepts and did improve in their mastery of these concepts when reassessed at the end of the academic year; however, these concepts should have been established earlier. Therefore, these students were behind in their development of these skills and thus, at risk of developing later literacy difficulties.

\subsection{Education in the rural areas of the Lubuskie region of Poland}

Although the quality of education in the Lubuskie Region has gradually been improving since the Ministry of Education launched the structural and program reforms in 1999 and 2009 respectively, the results the students achieve in the external exams stay below the country's average, especially so in the rural areas. Socio-economic indicators are unfavorable for Lubuskie region as well. For instance, data published by GUS (Central Statistical Office) show that people in Lubuskie are slightly poorer than the country's average. Also, in 2010, the average household expenditure on education in rural areas was only 7.10 zloty a month while in towns it was 16.26 zloty (Central Statistical Office 2011: 68).

Secondly, people inhabiting the rural areas have lower education-in 2010 only $9.3 \%$ of villagers had higher education, as compared to $23.6 \%$ of people living in towns and cities, similarly, $36.6 \%$ of rural and $61.4 \%$ of urban inhabitants had secondary education (Central Statistical Office 2011,68). The phenomenon called 'education inheritance' makes the situation worse; $72 \%$ of children whose parents had only primary education stop at that very level (Cichomski 2003). Moreover, 
in 2011 , only $42.7 \%$ of children in rural areas attended kindergarten in Lubuskie (Central Statistical Office 2011: 68).

The Poznań Regional Examination Board (OKE) published average student scores in external exams for primary, middle, and secondary education. They all have shown lower scores in schools in rural areas. In 2012, the average result of the primary school exam in Bogdaniec commune was 1.44 below the country's average, and in 2011, it was 2.04 below, in 2010, it was 0.7 below, and in 2009, it was 1.74 below the country's average (Poznań Regional Examination Board 2012). Likewise, in rural middle schools the results were lower. In 2011, the Bogdaniec commune had results below the country's average in humanities (by 2.85) and in mathematics and sciences (by 2.63) (Poznań Regional Examination Board 2012).

Additionally, the Examination Board reports show that average results of boys are lower than those of girls (Poznań Regional Examination Board 2012). These data are confirmed by research into school readiness of Polish six-year-olds, which revealed a considerable difference in scores to the disadvantage of boys (Kopik 2007). The 2011 President's Report "Educational chances in rural areas" states that the generally lower results in rural areas result from pre-school education insufficiency in those districts as well as from lower quality programs serving to prepare those children for schooling, especially with reference to their readiness to receive instruction developing early literacy and numeracy skills. The research cited in the report suggests that the level of early education correlates with the quality of human resources. High quality programs in pre-school are said to increase the opportunities to succeed both in education and in adult life and one of the key factors accounting for the quality of those programs is the teaching staff systematically raising their skills (The President's Report 2011: 35).

\subsection{Polish research}

The ongoing research commenced with a pilot study at two state preschools in the city of Gorzow Wielkopolski, Lubuskie Region in 2011. Twenty seven Polish speaking students participated in the pilot study. The students were reported to come from higher socio-economic status (see Gillian, Ferensztajn, Franków-Czerwonko, \& Paradowska, in press, for more details). The students' emergent literacy skills were assessed by the authors at the end of the academic year using a translation completed by the authors. The translation was done by all the authors under the supervision of the author who is a sworn translator (Franków-Czerwonko).

The next step of the Polish research is currently occurring in the Bogdaniec commune, Lubuskie Region, near the city of Gorzow Wielkopolski in five preschool classes at four primary schools. The research group from Państwowa Wyższa Szkoła Zawodowa (PWSZ) was hired by the head of the commune to 
develop the professional skills of the preschool teachers in the explicit teaching of emergent literacy and numeracy skills. The reason for the employment of the research group was that the head was reported to be concerned with the declining literacy and numeracy results in later primary school education in the commune. Ninety-seven Polish speaking students and eighteen preschool teachers and preschool directors are participating in this study and professional development programme.

The first step of this project was to explain the goals of the project to the parents and teachers and gain consent from the parents for their children to participate in the study. All the parents of the children attending the preschools consented to have their children participate in the project.

The first stage of the project was to provide professional development to the teachers in the use of the second version of Polish emergent language screener (see Figure 1 for some details about this screener). This professional development took the form of a two and half hour workshop conducted by the authors where the rationales of the screener, the English and Polish developmental norms for the concepts and the practical use of the screener were explained through lectures, visual aids, and group discussion.

The next stage was for the teachers to assess their students using the screener at the start of the academic year (see the results section for more details of the pre-assessment) and collect information on the backgrounds of the students. This information is currently collected, but many of the students were reported to come from lower socio-economic backgrounds (Jeż, Góralczyk, Mierzwa, Demczyszyn, personal communications).

The subsequent stage is to provide professional development on explicit teaching of the emergent language skills on the screener and the development of a teaching programme targeting the language concepts in the screener. The programme is taking the form of lesson plans developed jointly by the teachers and the researchers at the workshops. The lesson plans on particular concepts were collated by researchers after a workshop on a particular set of concepts; for example, spatial locational terms, and then emailed to the teachers the following week for use in the class room. The lesson plans are intended to cover the major areas of the curriculum: literacy, numeracy, physical education, foreign languages (English and German), and religion. The lesson plans also provide brief descriptions of the activities and resources needed to teach the concepts. The emergent language skills first focussed on were those the teachers identified as most important through the assessment by the screener (see results section for details on the concepts the students had most difficulties with). The teaching of each set of concepts in the lesson plans is meant to be focussed on by the teachers in all major areas of the curriculum for a minimum of two weeks or for as long as deemed necessary by the teachers to ensure that the students have mastered the concepts. 
The next stage will be to reassess the students' emergent language skills at the end of the academic year to gauge the students' progress with mastering these skills and assess the effectiveness of the teaching programme.

The final stage will be a follow-up step where the literacy and numeracy results of this cohort of students will be tracked in the later years of primary school to see if the emergent literacy and numeracy program has had any long term effects.

\section{Method}

\subsection{Australian checklist}

The English language emergent language screener was developed by the researcher, Gillian, at a number of Australian schools together with teachers (see Figure 1 for some details of the English screener). The English developmental norms for these basic language concepts were drawn from the Owens Jr. textbook Language Development: An Introduction (7 $7^{\text {th }}$ Edition) (see Gillian, Ferensztajn, Franków-Czerwonko, \& Paradowska, in press, for more details).

\subsection{Translation of the checklist in to Polish}

In 2011, the authors translated the English language screener of basic language skills into Polish for the purposes of the pilot study. The procedure mainly involved adapting some of the concepts to meet the semantic and syntactic rules of the Polish language. For example, 'on' as in 'Put the crayon on the pencil case' was replaced with 'na' as in 'Połóż kredkę na piórniku', 'in' was rendered as 'do' as in 'Włóż kredkę do piórnika' (Put the crayon in the pencil case), and ' $z$ ' as in 'Zabierz kredkę z piórnika' was translated as 'out of' ('Take the crayon out of the pencil case'). However, while administering the screener, the authors realised that to understand Polish instructions used for testing spatial locational terms children did not need to understand the prepositions; the verbs used, like 'połóż', 'włóż', 'zabierz', 'przesuń', implied the meaning of each concept. As they were all dynamic verbs the prepositions were actually redundant (see Figure 1 for more details).

In September 2012, when the screener was refined before commencing the Bogdaniec project, the authors decided to replace dynamic verbs with static ones. Now, children were asked either to illustrate the sentences read by the examiner, e.g. 'Miś jest w piórniku' (The teddy is in the bag') or 'Miś jest pod piórnikiem' (The teddy is under the bag), or follow her instruction: 'Połóż misia na górze/ na dole kartki' (Put the teddy at the top/bottom of the sheet of paper). Also, the authors rendered the English verbs 'put in' and 'take out of' as 'włóż' and 
'wyjmij' respectively, even though they are dynamic verbs that imply the meaning of the concepts of 'do' and ' $z$ '. These renditions were included as no other suitable renditions could be found.

Table 1. Comparison of the English screener and its Polish adaptations-spatial locational concepts

\begin{tabular}{|c|c|c|}
\hline English Screener & $\begin{array}{l}\text { Polish Screener v.1 } \\
\text { (2011) }\end{array}$ & $\begin{array}{l}\text { Polish Screener v.2 } \\
\text { (2012) }\end{array}$ \\
\hline Put the pen on the bag. & Połóż kredkę na piórniku. & Miś jest na piórniku. \\
\hline Put the pen in the bag. & Włóż kredkę do piórnika. & Włóż misia do piórnika. \\
\hline Take the pen out of the bag. & $\begin{array}{l}\text { Zabierz kredkę } \\
\text { z piórnika. }\end{array}$ & Wyjmij misia z piórnika. \\
\hline- & - & Miś jest w piórniku. \\
\hline- & - & Miś jest nad piórnikiem. \\
\hline Put the pen up/down. & $\begin{array}{l}\text { Przesuń kredkę do góryl } \\
\text { na dół. }\end{array}$ & Połóż misia na górze/na \\
\hline $\begin{array}{l}\text { Where is top/bottom of the } \\
\text { bag? }\end{array}$ & $\begin{array}{l}\text { Gdzie jest góra/dół } \\
\text { piórnika? }\end{array}$ & dole kartki. \\
\hline Put the pen under the bag. & $\begin{array}{l}\text { Połóż kredkę pod } \\
\text { piórnikiem. }\end{array}$ & Miś jest pod piórnikiem. \\
\hline Put the pen over the bag. & $\begin{array}{l}\text { Niech miś przeskoczy } \\
\text { przez piórnik. }\end{array}$ & - \\
\hline Where is your front/back? & $\begin{array}{l}\text { Gdzie jest twój przód/ } \\
\text { /tył? }\end{array}$ & $\begin{array}{l}\text { Gdzie jest przód/tył } \\
\text { misia? }\end{array}$ \\
\hline Put the pen on the left/right. & $\begin{array}{l}\text { Połóż kredkę po lewej/po } \\
\text { prawej stronie piórnika. }\end{array}$ & $\begin{array}{l}\text { Połóż misia po lewej/ } \\
\text { /prawej stronie kartki. }\end{array}$ \\
\hline
\end{tabular}

Another pair of commands that needed improvement was 'góra and 'dół'. The authors agreed that both 'up/down' and 'top/bottom' may be rendered in Polish as 'góra/dół', the four English concepts were replaced with two Polish ones: The sentences: 'Put the pen up/down' (translated in 2011 as 'Przesuń kredkę do góry/ na dól') and 'Where is top/bottom of the bag?'(translated in 2011 as 'Gdzie jest góra/dół piórnika?' became one: 'Połóż misia na górze/na dole kartki'. Also, the authors added two more concepts of ' $w$ ' and 'nad', which, they concluded, were important for developing literacy and numeracy in the Polish language. At the same time, the English concept of 'over' was removed from the Polish version of the test because (1) the Polish sentence: 'Niech miś przeskoczy przez piórnik' 
sounded unnatural and (2) the knowledge of 'przez' does not seem to be necessary for developing literacy and numeracy. Similarly, the unnatural instruction: 'Gdzie jest twój przód/tył?' (Where is your front/back?) was replaced with: 'Gdzie jest przód/tył misia?' (Where is the teddy's front/back?).

Another amendment made while refining the screener was the choice of Polish words to test children's mastery of beginning and end sounds in words. The 2011 version used 'kot', 'pies', 'miś' for identifying sounds at the beginning of words; whereas, the 2012 version included 'gol', 'park', and 'nos'. The authors decided to replace the words because children in the pilot study would identify the first sounds as [pie] and [mi] rather than [p] and [m]. As for the final sounds, the words 'hop', 'płot', and 'dom' were replaced with 'sklep', 'kot', and 'dom'. The selected words had to be one-syllable words with clear pronunciation of beginning and end sounds.

\section{Data Analysis}

\subsection{Pilot study overall results-Comparison of Polish preschools' performance to Australian school's performance}

For the pilot study, the data indicated that the Polish five year old students achieved a similar performance to the students in the Australian school. The pilot study data indicated that $90 \%$ percent of the students in Polish preschool 1 and $75 \%$ of the students in Polish preschool 2 achieved the criterion score employed in the English emergent language screener. This was slightly higher than the percentages of students who achieved the criterion score in the two Australian classes ( $86 \%$ and $85 \%$ respectively). The differences between the groups were not statistically significant (Welch's t-test, $\mathrm{t}(68)=0.9697, \mathrm{P}<.05$ ). (see Gillian, Ferensztajn, Franków-Czerwonko, \& Paradowska, in press, for more details). However, when examining these statistics, two important factors need to considered: the Australian students received year-long explicit intervention to develop these concepts; whereas, the Polish students did not, and the majority of the Australian students received the literacy instruction in English which was not their first language (see Gillian, Ferensztajn, Franków-Czerwonko, \& Paradowska, in press, for more details).

\subsection{Sound Identification}

There was one interesting trend from the pilot study in the area of identification of sounds. In this area, the Polish students in preschools 1 and 2 achieved significantly lower scores than the scores of the two Australian classes (see Figure 2 for more details). This difference in the scores was found to be extremely statistically 
significant (Welch's t-test, $\mathrm{t}(67)=4.5575, \mathrm{P}<.05)$ with the Polish students scoring lower than the Australian students $\left(\mathrm{Mpol}=2.11, S D=0.85, N=27 ; M_{\text {aus }}=3.36\right.$, $S D=1.25, N=42$ ) (see Gillian, Ferensztajn, Franków-Czerwonko, \& Paradowska, in press, for more details).

\subsection{Comparison of Bogdaniec preschools' overall performance to Australian schools}

The overall pre-assessment results of the Bogdaniec preschools were better than the Australian schools at the start of the academic year. The students at the Australian schools achieved criterion scores of $4 \%$ and $5 \%$ respectively (see Figure 2 for more details). Eighty-eight percent of the Bogdaniec A group achieved the criterion score. When comparing Bogdaniec A to Australian groups, this difference was statistically significant (Welch's t-test, $\mathrm{t}(52)=7.4854, \mathrm{P}<.05$ ). For the other groups in the Bogdaniec commune, they achieved respectively criterion scores of $18 \%, 36 \%, 38 \%$, and 41\%. When comparing Bogdaniec A to the other Polish groups, the difference was also statistically significant (Welch's t-test, t(25) = $4.5058, \mathrm{P}<.05)$. Finally, when comparing the Polish groups excluding Bogdaniec A to the Australian groups, the difference was statistically significant (Welch's t-test, $t(53)=5.0471, P<.05)$. However, it should be remembered that the majority of the Australian students were not receiving their literacy and numeracy instruction in their first language; whereas, the Polish students were.

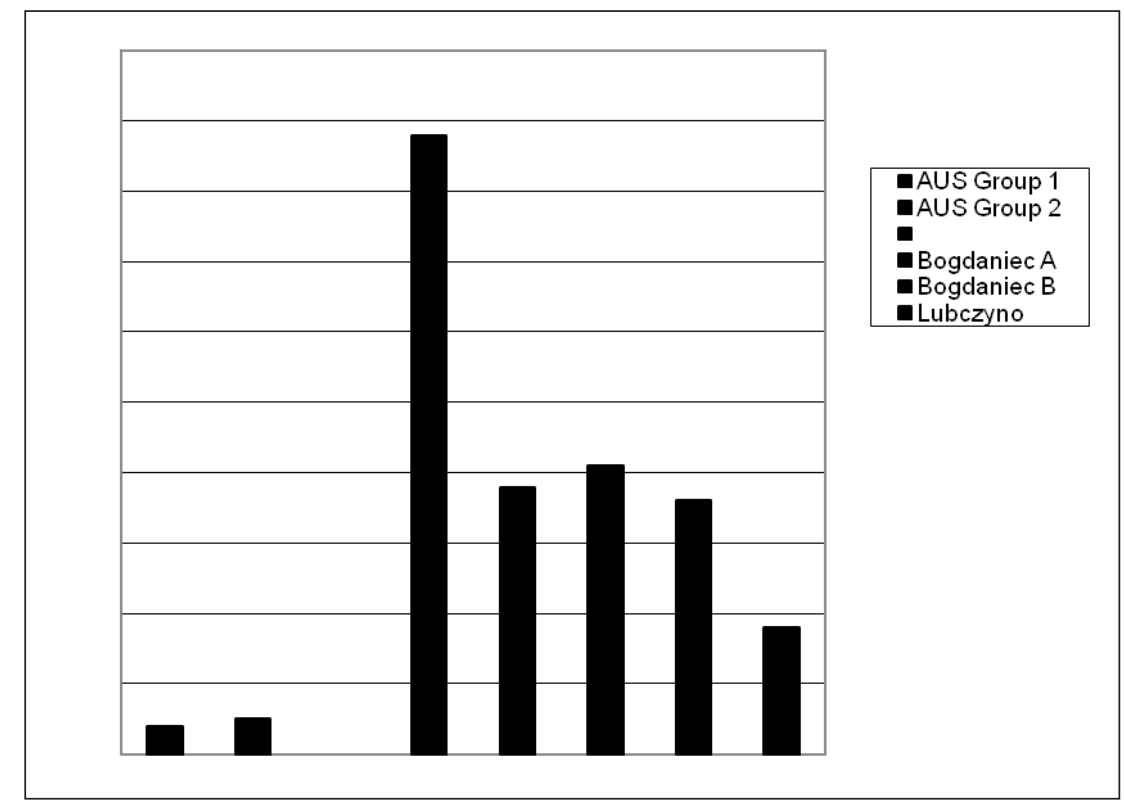

Figure 1. Comparison of the English and Polish emergent literacy scores-start of the year 


\subsection{Comparison of selected areas- Bogdaniec commune and Australian schools}

When comparing the pre-assessment results for the Bogdaniec commune to the Australian schools, the Polish students and Australian students achieved similar results for the concept groups of body parts, gender, and colour.

The Polish students were better at identifying spatial/locational terms, texture, and beginning/end than the Australian students. The Australian students varied greatly in the identification of spatial/locational concepts, with $28 \%$ of group 1 achieving criterion and 94\% of group 2 achieving criterion in this area (see Figure 3 for more details). The Bogdaniec groups achieved between $63 \%$ and $94 \%$ in this area (see Figure 2 for more details). The teachers reported that many students across all the groups had difficulties with identifying 'góra' and 'dól' in both horizontal and vertical directions. The Polish teachers also reported that some students had difficulties with identifying ' $n a$ ' —'on' and 'nad' —'over/above'. For texture, the Bogdaniec groups achieved between $81 \%$ and $88 \%$ in this area; whereas, the Australian groups achieved $14 \%$ and $22 \%$, respectively (see Figure 3 for more details). For physical sequencing (i.e. identifying beginning/end), the Bogdaniec groups achieved between $70 \%$ and $100 \%$ in this area; whereas, the Australian groups achieved $45 \%$ and $44 \%$, respectively (see Figure 3 for more details).

For the concept areas of sounds, the Australian groups achieved better results than the Bogdaniec A group. While there was a difference in the means for this concept group (Australian groups mean was 7.53 while the Bogdaniec A mean was 6.13), this difference was not statistically significant. The Australian groups achieved the criterion $45 \%$ and $22 \%$ respectively; whereas, $6 \%$ of Bogdaniec B, $13 \%$ of Jeniniec, $29 \%$, and $30 \%$ of Lubczyno students achieved the criterion score in this area. When comparing the Polish groups excluding Bogdaniec A to the Australian groups in the concept are of sounds, the difference was statistically significant (Welch's $t$-test, $t(98)=3.2640, \mathrm{P}<.05$ ), with the Boganiec groups excluding Bogdaniec A scoring lower than the Australian students (Mbog $=5.70$, $S D=3.28, N=79 ; M_{\text {aus }}=7.53, S D=2.79, N=42$ ). Interestingly, the Bogdaniec B teachers reported that the students had good skills with identifying beginning sounds in one syllable words, but had difficulties in identifying end sounds in words, which was a similar result to the results of the pilot study. 


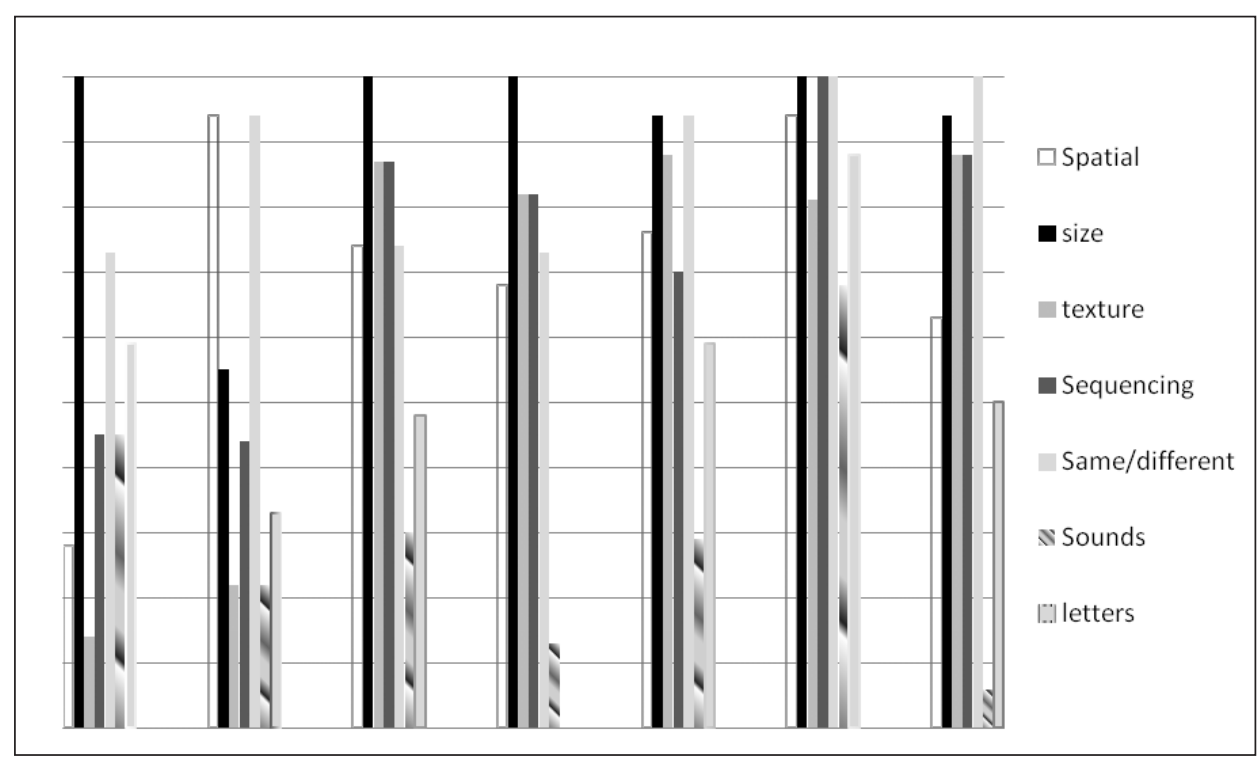

Figure 2. Comparison of the English and Polish emergent literacy section scores-start of the year

\section{Conclusion}

1. The importance of early language concepts has been proved to have a significant influence on later educational skills of students in English.

2. The research from English speaking countries, and the specific Australian research conducted by the author, Gillian, show that students who are given explicit teaching in the early language concepts have a chance to improve in their mastery of these concepts.

3. The students from the Lubuskie region in Poland have been performing poorly on their external exams, as proved by the average student scores included in the data published by Central Statistical Office and the Poznań Regional Examination Board.

4. The majority of the concepts were translated from English to Polish with appropriate equivalence. However, the translators had difficulties finding appropriate equivalents for some spatial/locational terms. The main difference is that these concepts/relationships are expressed with prepositions in English; whereas, in Polish, they are expressed through a combination of dynamic verbs and prepositions.

5. The Polish students in the pilot study and the Bogdaniec commune achieved similar results to the Australian students in the concept areas of body parts, gender, and colour. The Polish students achieved better results than the Australian students for the concept areas of spatial/locational terms, 
texture, and beginning/end. However, the Polish students had difficulties with identifying the concepts 'góra/dół' in both the horizontal and vertical directions. The Polish students achieved worse results than the Australian students in the concept areas of identifying sounds, particularly end sounds in words (see Gillian, Ferensztajn, Franków-Czerwonko, \& Paradowska, in press, for possible hypotheses).

6. One objective of the authors is to assess the Polish students in terms of their emergent literacy and numeracy concepts and provide them with explicit teaching of these concepts through training their teachers during workshops conducted by the authors. The research is presently continuing and the post assessment will be completed in June 2013.

7. The authors' intention is that this teaching intervention will increase skills and knowledge of the pre-school students and teachers in the Bogdaniec commune and that the students will have a chance to improve their average literacy and numeracy test scores in the future.

\section{References}

Bishop, D.V M., Adams, C. 1990. A prospective study of the relationship between specific language impairment, phonological disorders, and reading retardation. Journal of Child Psychology and Psychiatry, 31: 1027-1050.

Catts, H.W. 1993. The relationship between speech-language impairments and reading disabilities. Journal of Speech and Hearing Research, 36: 948-958.

Catts, H.W., Fey, M.E., Tomblin, J.B., Zhang, X. 2002. A longitudinal investigation of reading outcomes in children with language impairments. Journal of Speech, Language, and Hearing Research, 45: 1142-1157.

Central Statistical Office. 2012. Statistical Yearbook of the Republic of Poland. Accessed November 25, 2012.http://www.stat.gov.pl/cps/rde/xbcr/gus/rs_rocznik_statystyczny_rp_2011.pdf

Cichomski, B. 2003. Artykuł w dziale edukacja. Biuletyn Ministra Nauki i Szkolnictwa Wyższego (wydania archiwalne). http://www.sprawynauki.waw.pl/?section=article\&art_id=418. Accessed November 25, 2012.

Dickinson, D.K., Anastasopoulos, L., McCabe, A., Peisner-Feinberg, E.S., \& Poe, M.D. 2003. The comprehensive language approach to early literacy: The interrelationships among vocabulary, phonological sensitivity, and print knowledge among preschool-aged children. Journal of Educational Psychology, 95(3): 465-481.

Fleer, M., Ridgway, A., Clarke, B., Kennedy, A., Robbins, J., May, W., \& Surman, L. 2006. Catch the future: Literacy and numeracy pathways for preschool children.http:// www.dest.gov.au/literacynumeracy/innovativeprojects/pdf/fleer_catch_future.pdf. Accessed August 19, 2007.

Gillian, E., Williamson, S. 2009. Oral Language Basic Concepts Programme: An example of collaborative service provision in Victoria. ACQuiring Knowledge in Speech, Language and Hearing, 11(2): 97-99.

Gillian, E., Ferensztajn, B., Franków-Czerwonko, B., Paradowska, U. (in press). Phonological awareness in Polish and Australian preschool children. Proceedings of the $1^{\text {st }}$ International Scientific Conference: State and perspectives of language learning in the light of European educational requirements. 
Gillon, G.T. 2005. Phonological Awareness: Effecting Change Through the Integration of Research Findings. Language, Speech and Hearing Services in Schools, 36: 346-349.

Gruszczyk-Kolczyńska, E., Zielińska, E. 1997. Dziecięca matematyka, Warszawa, WSiP.

Hogan T.P., Catts, H.W., Little T.D. 2005. The relationship between phonological awareness and reading: Implications for the assessment of phonological awareness. Language, Speech and Hearing Services in Schools, 36: 285-293.

Justice, L.M., Kaderavek, J.N., Fan, X., Sofka, A., Hunt, A. 2009. Accelerating preschoolers' early literacy development through classroom-based teacher-child storybook reading and explicit print referencing. Language, Speech and Hearing Services in Schools, 40(1): 67-85.

Janiszewska, B. 2008. Ocena dojrzałości szkolnej, Warszawa, Wyd. Seventh Sea.

Justice, L.M., Invernizzi, M.A., \& Meier, J.D. 2002. Designing and implementing an early literacy screening protocol: Suggestions for the speech-language pathologist. Language, Speech and Hearing Services in Schools, 33(2): 84-101.

Kopik, A. (Ed.) 2007. Sześciolatki w Polsce: raport 2006: diagnoza badanych sfer rozwoju. Kielce-Bydgoszcz: Wydawnictwo Tekst.

Louden, B. 2010. Index of Community socio-educational advantage [ICSEA]. Paper presented at Socioeconomic Status and Higher Education Students Symposium, University of Technology of Sydney, Sydney, 12 April 2010.

Matczak, A. 2003. Zarys psychologii rozwoju. Podręcznika dla nauczycieli, Warszawa, Wydawnictwo Żak.

Office of the President of the Republic of Poland. 2011. Potencjal Obszarów Wiejskich Szansa Rozwoju: Spotkanie drugie: Szanse edukacyjne na obszarach wiejskich. http://www. prezydent.pl/dialog/fdp/potencjal-obszarow-wiejskich-szansa-rozwoju-/materialy/ Accessed November 25, 2012.

Owens Jr., R.E, 2008. Language Development: An Introduction ( $7^{\text {th }}$ Edition). Allyn \& Bacon. Boston, MS.

Pasnak, R., MacCubbin, E., Ferral-Like, M. 2007.Using developmental principles to assist preschoolers in developing numeracy and literacy. Perceptual and Motor Skills, 105: 163-176.

Poznań Regional Examination Board. 2012. Średnie wyniki sprawdzianu w szkole podstawowej z podziałem na umiejętności (arkusze S1, S4, S5, S6) - układ terytorialny. http://www. oke.poznan.pl/admin/cms,1868,wyniki_gmin_powiatow_wojewodztw.htm. Accessed November 25, 2012.

Torgesen, J., Wagner, R., Raschotte, C. 1994. Longitudinal studies of phonological processing and reading. Journal of Learning Disabilities. 27: 276-286. 